\title{
MATERNAL SERUM ALPHA-FETOPROTEIN LEVELS AND FETAL OUTCOME IN EARLY SECOND-TRIMESTER OLIGOHYDRAMNIOS
}

\author{
FRANS J, LOS*, ADRIANA M. HAGENAARS $\dagger$, JAN MARRINK $\ddagger$, \\ TITIA E. COHEN-OVERBEEK§, JOHANNES L. J. GAILLARD\| AND HELEN BRANDENBURG§ \\ Departments of Clinical Genetics* and Obstetrics and Gynaecology§. University Hospital Dijkzigt, \\ Rotterdam, The Netherlands; †Department of Teratology, Endocrinology and Perinatal Screening, \\ National Institute of Public Health and Environmental Protection (RIVM), Bilthoven. The Netherlands; \\ $\ddagger$ Laboratory of Immunochemistry, Department of Internal Medicine, University Hospital, Groningen, \\ The Netherlands; $\|$ Foundation for Cytodiagnostic Research, Rotterdam. The Netherlands
}

\begin{abstract}
SUMMARY
Early second-trimester oligohydramnios was associated with normal maternal serum alphafetoprotein (MSAFP) levels in nine out of 26 cases ( 35 per cent). Congenital malformations of the fetal urinary tract resulting in fetal anuria were present in nine cases; in seven of them, normal MSAFP levels were measured. In contrast, normal MSAFP levels were established in only 2 out of the 17 cases without fetal malformations. These data suggest that fetal urine is the major source of elevated AFP in the maternal compartment in early second-trimester oligohydramnios. This is further supported by the lack of any relationship between concentrations of MSAFP non-reactive with Concanavalin A, originating mainly from the yolk sacderived amniotic fluid AFP pool, and the presence of fetal diuresis. Three out of 26 women had experienced early second-trimester oligohydramnios in a previous pregnancy, suggesting the existence of a recurrence risk for this condition.
\end{abstract}

KEY WORDS Alpha-fetoprotein Concanavalin A Fetal malformations Oligohydramnios

\section{INTRODUCTION}

Various reports have appeared on the association between raised levels of maternal serum alpha-fetoprotein (MSAFP) and early second-trimester oligohydramnios (Dyer et al., 1987; Richards et al., 1988; Kelly et al., 1989). Dericks-Tan et al. (1982) established raised MSAFP concentrations in women suffering from rupture of the fetal membranes prior to 20 weeks of gestation.

Recently it has been shown that AFP in amniotic fluid is the source of the rise in MSAFP levels in second-trimester oligohydramnios, probably due to a defect in the fetal membranes (Los et al., 1992). This report also documented normal MSAFP levels in early second-trimester oligohydramnios in three cases, of which two had malformations of the fetal urinary tract, causing fetal anuria or oliguria. In this study of an extended series of women with early second-trimester oligohydramnios, we report the finding of normal MSAFP levels, especially in the presence of congenital malformations of the fetal urinary tract resulting in fetal oliguria or anuria.

Addressee for correspondence: F. J. Los, MD, Department of Clinical Genetics, University Hospital Dijkzigt, Erasmus University, P.O. Box 1738, 3000 DR Rotterdam, The Netherlands. 


\section{MATERIALS AND METHODS}

Between September 1988 and May 1991, 29 women with early second-trimester oligohydramnios were detected among 3300 pregnant women referred for ultrasound investigation to the prenatal diagnostic centre of the University Hospital Dijkzigt, Rotterdam. Gestational age varied between 15 and 20 weeks (median 18 weeks). Ultrasound investigation involved two-dimensional real-time assessment of fetal size and structure, placental localization, and amniotic fluid volume. A linear array two-dimensional real-time system (Toshiba SSA-270A, 3.75 MHz) was used. Oligohydramnios was diagnosed when the largest pocket of amniotic fluid measured up to $2 \mathrm{~cm}$ (Los et al., 1992).

Blood samples for MSAFP measurement of 26 of these 29 women were spun down twice, and the sera stored at $-20^{\circ} \mathrm{C}$ until assay. MSAFP concentrations were measured with a polyclonal enzyme-linked immunosorbent assay (ELISA) (Los et al., 1989). The cut-off level of 2.5 multiples of the median value (MOM) was used for the definition of raised MSAFP levels (U.K. Collaborative Study, 1977), representing the 97 th centile (Los et al., 1992).

Measurement of non-Concanavalin A-reactive MSAFP concentrations was carried out as described previously with a three-stage monoclonal antibody ELISA (Marrink et al., 1990; Los et al., 1992).

Fetal birth weights were related to reference weight for gestation figures according to Exalto (1979) up to 19 weeks and according to Kloosterman (1970) for the remainder of the pregnancy.

The Wilcoxon rank sum test was applied for comparison of MSAFP levels in women carrying normal fetuses and those carrying fetuses with congenital anomalies of the urinary tract. Distribution frequencies of normal versus abnormal MSAFP levels in relation to normal or abnormal fetal outcome were studied with the Fisher exact test, and of fetal sex with binomial statistics.

\section{RESULTS}

Congenital malformations were diagnosed in 9 out of 26 women with oligohydramnios. All anomalies were related to the fetal urinary tract, and were confirmed by necropsy (Table 1). Of the 17 cases without fetal abnormalities, 14 were confirmed by necropsy; in two cases, no post-mortem examination was carried out and in one case, a live infant was born (Table 2). Two fetuses were severely growth-retarded as established by ultrasound (cases 25 and 26, Table 2). In three instances, the fetus displayed undetected moderate growth retardation (cases 14, 19, and 20, Table 2).

MSAFP concentrations ranged between 39 and $272 \mu \mathrm{g} / \mathrm{l}($ median $158 \mu \mathrm{g} / \mathrm{l})$ in the group without fetal anomalies, and between 47 and $157 \mu \mathrm{g} / \mathrm{l}$ (median $88 \mu \mathrm{g} / \mathrm{l}$ ) in the group with fetal urinary tract malformations. This difference in level is statistically significant (Wilcoxon rank sum test, $p<0 \cdot 01$ ). Normal MSAFP levels were found in 9 out of 26 women ( 35 per cent), seven of which carried a fetus with urinary tract anomalies (Figure 1). The remaining two fetuses were normal (cases 16 and 26, Table 2 ). In the 17 women ( 65 per cent) with raised MSAFP levels, only two carried a fetus with a urinary tract malformation (cases 1 and 4, Table 1; Figure 1). This 
Table 1. Ultrasound diagnosis and post-mortem findings in the nine women with fetal malformations. Classification of cystic kidneys (types I-IV) according to Zerres et al. (1984)

\begin{tabular}{|c|c|c|c|}
\hline Case & $\begin{array}{l}\text { Weeks of } \\
\text { gestation }\end{array}$ & $\begin{array}{l}\text { Ultrasound } \\
\text { findings }\end{array}$ & Fetal outcome \\
\hline 1 & 19 & $\begin{array}{l}\text { Spina bifida, hydrocephaly, } \\
\text { bilateral renal agenesis }\end{array}$ & $\begin{array}{l}\text { TOP, } 19 \cdot 5 \text { weeks, },+250 \mathrm{~g} \text {, spina } \\
\text { bifida, bilateral renal agenesis, } \\
46, \mathrm{XX}\end{array}$ \\
\hline 2 & 18 & $\begin{array}{l}\text { Enlarged urinary bladder, } \\
\text { bilateral hydronephrosis }\end{array}$ & $\begin{array}{l}\text { TOP, } 19 \text { weeks, } \delta, 600 \mathrm{~g} \text {, distal } \\
\text { urethral obstruction, distended } \\
\text { bladder, cystic kidneys type IV, } \\
46, \mathrm{XY}\end{array}$ \\
\hline 3 & 20 & $\begin{array}{l}\text { Multicystic kidneys, no } \\
\text { bladder filling }\end{array}$ & $\begin{array}{l}\text { TOP, } 20 \cdot 5 \text { weeks, } 0 \text {, cystic } \\
\text { kidneys type II B, } 46, X Y\end{array}$ \\
\hline 4 & 16 & $\begin{array}{l}\text { Enlarged urinary bladder, } \\
\text { bilateral hydronephrosis }\end{array}$ & $\begin{array}{l}\text { TOP, } 19 \text { weeks, }, \text {, urethral } \\
\text { agenesis, distended bladder, } \\
\text { hydronephrosis, } 46, \mathrm{XX}\end{array}$ \\
\hline 5 & 17 & $\begin{array}{l}\text { Enlarged urinary bladder, } \\
\text { hydronephrosis (left) }\end{array}$ & $\begin{array}{l}\text { TOP, } 19 \text { weeks, } 0,295 \mathrm{~g}, \\
\text { urethral hypoplasia, dilated } \\
\text { bladder, hydronephrosis, } 46, \mathrm{XY}\end{array}$ \\
\hline 6 & 20 & $\begin{array}{l}\text { Multicystic kidney (right), } \\
\text { renal agenesis (left), no } \\
\text { bladder filling }\end{array}$ & $\begin{array}{l}\text { TOP, } 20 \text { weeks, } 0,260 \mathrm{~g} \text {, cystic } \\
\text { kidney type Il A (right), renal } \\
\text { agenesis (left), rocker bottom } \\
\text { feet, ulnar deviation of dig. } \\
\text { II-IV, trisomy } 11 \text { (q21 } \rightarrow \text { qter)* }\end{array}$ \\
\hline 7 & 19 & $\begin{array}{l}\text { Bilateral renal agenesis, no } \\
\text { bladder filling }\end{array}$ & $\begin{array}{l}\text { TOP, } 19 \text { weeks, ô, } 250 \mathrm{~g} \text {, } \\
\text { bilateral renal agenesis, } \\
\text { syndactyly, cryptophthalmus } \\
\text { (phenotype } 219000 ; \text { McK usick, } \\
\text { 1990), } 46, \mathrm{XY}\end{array}$ \\
\hline 8 & 16 & $\begin{array}{l}\text { Renal dysplasia/agenesis, no } \\
\text { bladder filling }\end{array}$ & $\begin{array}{l}\text { TOP, } 17 \text { weeks, } \precsim, 125 \mathrm{~g} \text {, } \\
\text { hypoplastic ureter and cystic } \\
\text { kidney type IV (right), renal } \\
\text { agenesis (left) }\end{array}$ \\
\hline 9 & 18 & $\begin{array}{l}\text { Bilateral renal agenesis, no } \\
\text { bladder filling }\end{array}$ & $\begin{array}{l}\text { TOP, } 19 \text { weeks, } \sigma^{\star} \text {, bilateral renal } \\
\text { agenesis, } 46, \mathrm{XY}\end{array}$ \\
\hline
\end{tabular}

TOP $=$ Termination of pregnancy.

*Fetal karyotype: $46, X Y,-8$, + rec $(8)(8 q$ ter $\rightarrow 8 \mathrm{p} 23:: 11 \mathrm{q} 21 \rightarrow 11 \mathrm{qter}), \mathrm{t}(8 ; 11)$ mat. Maternal karyotype: $46, X X, t(8 ; 11)(8 q 12 \rightarrow 8$ p23:: 1 lq21 $\rightarrow 1$ l qter; 11 pter $\rightarrow 11$ q2 $1:: 8 q 12 \rightarrow 8 q$ ter $)$ mat.

difference in the incidence of fetal urinary tract anomalies between the group with normal and the group with raised MSAFP levels is statistically significant (Fisher exact test, $p=0.0016$ ).

Concentrations of non-Concanavalin A-reactive MSAFP ranged between 2 and $12 \mu \mathrm{g} / 1$ (median $7 \mu \mathrm{g} / \mathrm{l}$ ) in the 17 women without fetal malformations, and between 4 and $9 \mu \mathrm{g} / 1$ (median $6 \mu \mathrm{g} / \mathrm{l})$ in the nine women with fetal urinary tract anomalies (Figure 2). This difference is not statistically significant (Wilcoxon rank sum test, $0.05<p<0.95$ ).

Fetal sex was female in six and male in 20 cases; this gender distribution towards a male fetal outcome was statistically significant (binomial statistics, $p=0.0047$ ). 
Table 2. Ultrasound diagnosis and fetal outcome in 17 women with early second-trimester oligohydramnios without fetal malformations

\begin{tabular}{|c|c|c|c|}
\hline Case & $\begin{array}{l}\text { Weeks of } \\
\text { gestation }\end{array}$ & $\begin{array}{l}\text { Additional } \\
\text { ultrasound } \\
\text { findings }\end{array}$ & Fetal outcome \\
\hline 10 & 19 & & IUD, 24 weeks, $440 \mathrm{~g}, 46, \mathrm{XY}$ \\
\hline 11 & 18 & & $\mathrm{PD}, 22$ weeks, $\sigma^{*}, 440 \mathrm{~g},+\mathrm{pp}, 46, \mathrm{XY}$ \\
\hline 12 & 16 & & IUD, 18 weeks, $\delta$, no necropsy \\
\hline 13 & 20 & & PD, 26 weeks, $ð, 745 \mathrm{~g}, \dagger \mathrm{pp}$ \\
\hline 14 & 18 & & IUD, 20 weeks, $\partial, 160 \mathrm{~g}$ \\
\hline 15 & 16 & No additional & IUD, 17 weeks, $\not, 210 \mathrm{~g}$ \\
\hline 16 & 16 & findings & 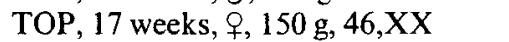 \\
\hline 17 & 15 & & TOP, 19.5 weeks, $\delta, 265 \mathrm{~g}$ \\
\hline 18 & 16 & & IUD, 22 weeks, $\delta, 370 \mathrm{~g}$ \\
\hline 19 & 19 & & IUD, 20 weeks, $\delta, 200 \mathrm{~g}$, no necropsy \\
\hline 20 & 17 & & IUD, 17 weeks, $\delta, 100 \mathrm{~g}$ \\
\hline 21 & 20 & & IUD, 22 weeks,,$+ 380 \mathrm{~g}$ \\
\hline 22 & 18 & & TOP, 22 weeks, $q, 310 \mathrm{~g}, 46, \mathrm{XX}$ \\
\hline 23 & 20 & & PD, 25 weeks, $\delta^{7}, 830 \mathrm{~g}$, tpp $, 46, X Y$ \\
\hline 24 & 17 & $\begin{array}{l}\text { Increase in AF } \\
\text { volume after } 20 \text { weeks }\end{array}$ & $\begin{array}{l}\mathrm{PD}, 35 \text { weeks, } 3,2230 \mathrm{~g} \text {, lung } \\
\text { hypoplasia, postural deformities; } \\
\text { presently well }\end{array}$ \\
\hline 25 & 18 & Signs of IUGR & IUD, 22 weeks, $3,100 \mathrm{~g}$ \\
\hline 26 & 19 & Signs of IUGR & TOP, 20 weeks, $Q, 65 \mathrm{~g}, 46, \mathrm{XX}$ \\
\hline
\end{tabular}

$\mathrm{AF}=$ Amniotic fluid; IUGR = intrauterine growth retardation; TOP = termination of pregnancy; $\mathrm{PD}=$ premature delivery; $\nmid \mathrm{pp}=$ fetal death post-partum; IUD $=$ intrauterine death.

Twenty-two out of 26 women were multigravidae, seven of whom displayed a fetal urinary tract anomaly. Three out of these seven women had experienced the same fetal anomaly in a previous pregnancy. In one of these women (case 5, Table 1), there had also been early second-trimester oligohydramnios and a male fetus; in the other two women (cases 7 and 8, Table 1), there had only been late second- and thirdtrimester oligohydramnios. In the remaining 15 women without a fetal anomaly, two had experienced early second-trimester oligohydramnios in a previous pregnancy. In both instances, a male fetus was delivered (cases 19 and 21, Table 2).

\section{DISCUSSION}

Normal MSAFP levels were measured in 9 out of 26 women with early secondtrimester oligohydramnios (35 per cent). In seven of these nine women, congenital malformations of the fetal urinary tract, resulting in fetal anuria or oliguria, were present. Fetal anuria has been suggested to be one of the predisposing factors for damage of the fetal membranes with subsequent early second-trimester oligohydramnios (Los et al., 1992). Second-trimester oligohydramnios associated with raised MSAFP levels occurred in only two of the nine women with fetal anuria. Normal fetal diuresis therefore seems to be the major source of the raised MSAFP 


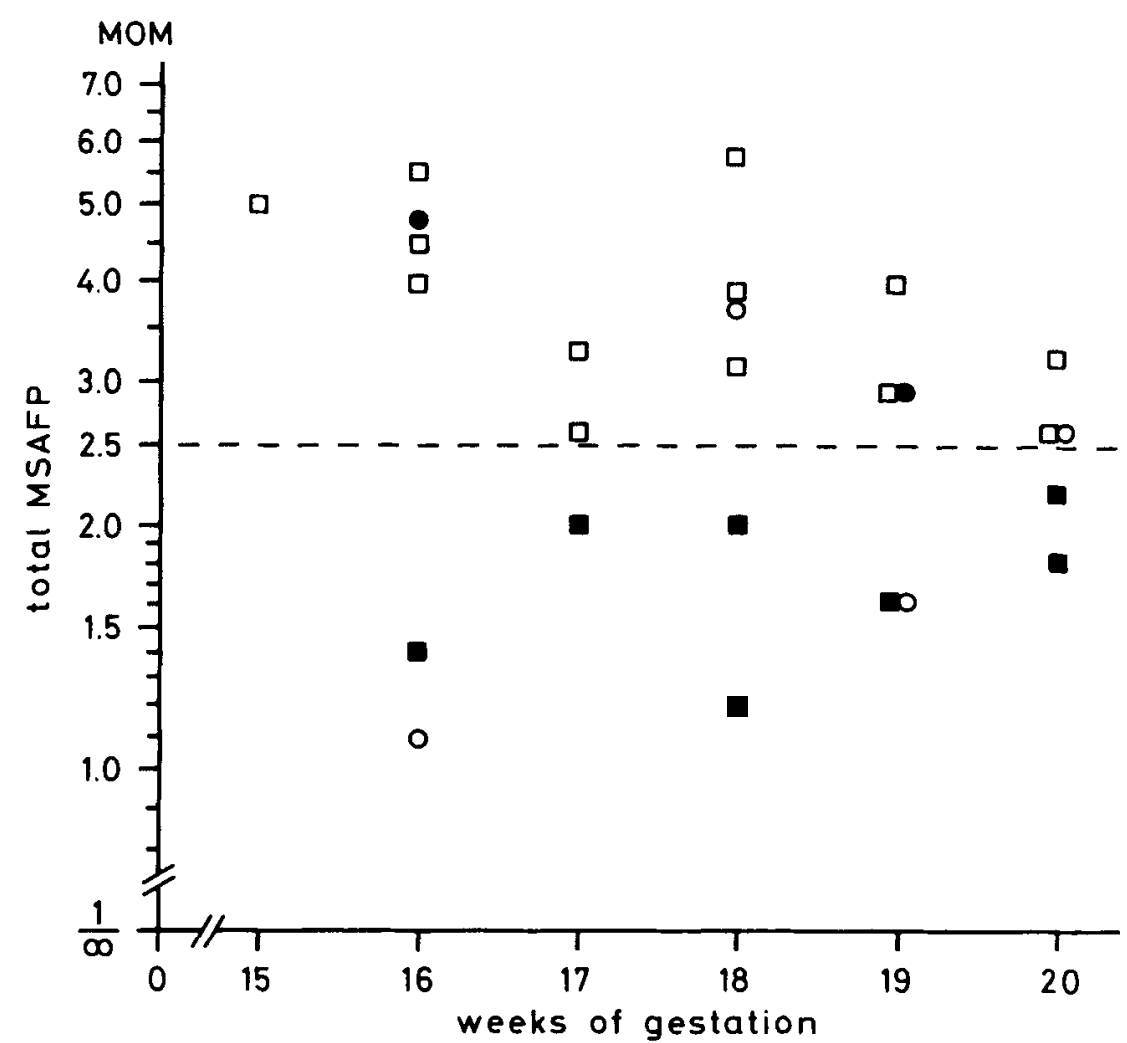

Figure 1. Levels of total MSAFP (MOM). Open circles/squares denote female/male fetuses without congenital malformations; closed signs, those with congenital malformations

levels in this condition, assuming that diuresis was normal in the presence of a normal fetus.

Amniotic fluid AFP originates from different sources: fetal urine, secretions from the fetal gastrointestinal and respiratory tracts, diffusion across the fetal skin, and from the fetal vessels in the umbilical cord and chorionic plate (Sutcliffe, 1975; Ruoslahti and Seppälä, 1979). A further source during the first trimester of pregnancy is the yolk sac, contributing especially non-Concanavalin A-reactive AFP to the amniotic fluid AFP pool (Ruoslahti et al., 1978).

Fetal urine is considered to be the major source of amniotic fluid AFP (Brock, 1976). However, fetal anuria would have little effect on the non-Concanavalin A-reactive AFP pool of amniotic fluid as the fetal compartment contributes only a low percentage of non-Concanavalin A-reactive AFP to amniotic fluid (Ruoslahti et al., 1978; Toftager-Larsen, 1990). The difference in median total and nonConcanavalin A-reactive MSAFP concentrations of $70 \mu \mathrm{g} / \mathrm{l}$ (158 minus 88) and $1 \mu \mathrm{g} / 1$ ( 7 minus 6) between the groups with and without fetal anomalies is compatible with the lack of an AFP source containing a low percentage of non-Concanavalin Areactive $A F P$ in fetal anuria.

A reduced fetal weight for gestational age was observed in five fetuses, all without fetal malformations. Early intrauterine growth retardation is known to be 


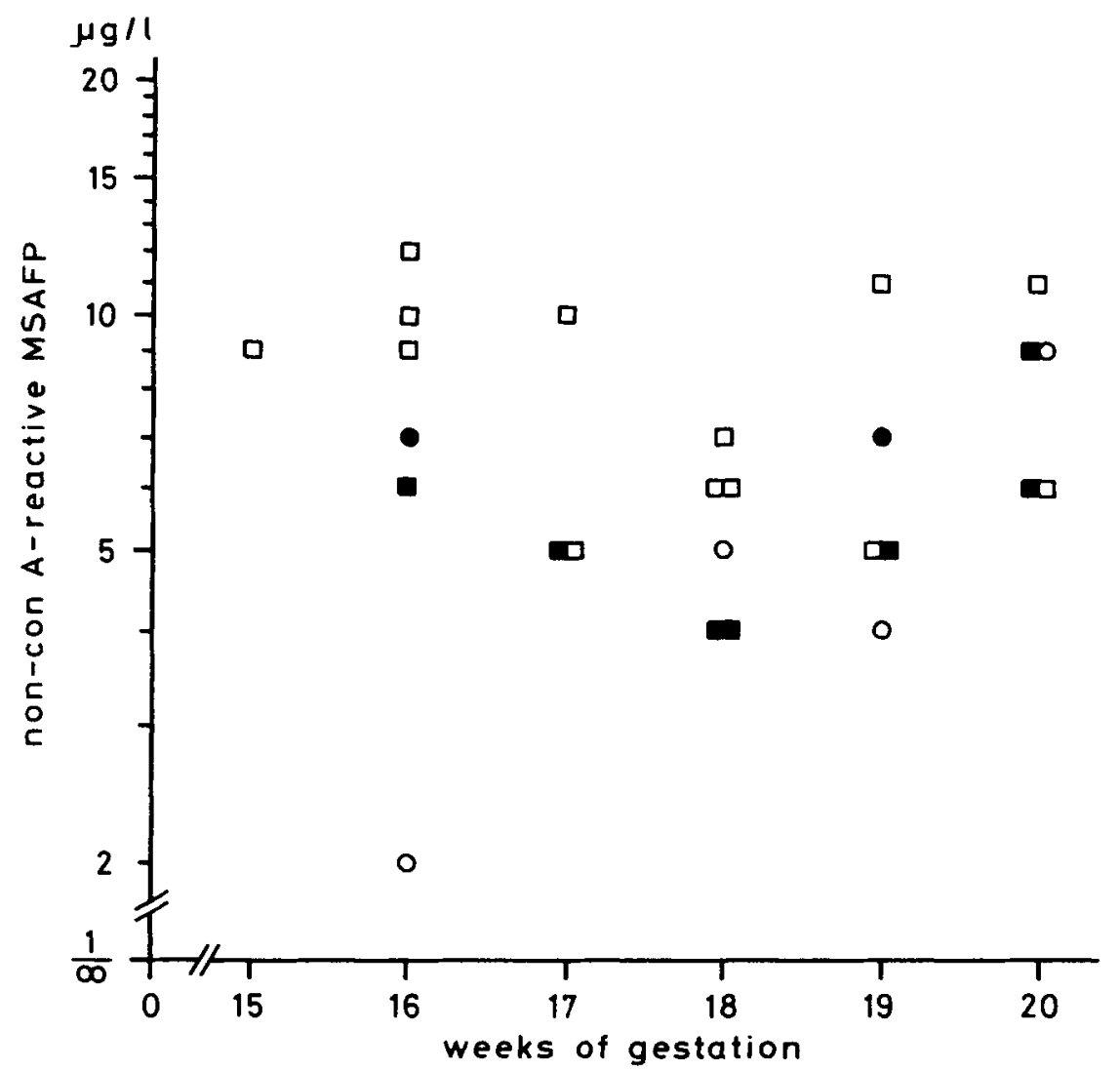

Figure 2. Concentrations of non-Concanavalin A-reactive MSAFP $(\mu \mathrm{g} / 1)$. See legends of Figure 1 for meaning of symbols

associated with second-trimester oligohydramnios due to reduced fluid supply to the amniotic fluid compartment (Hackett et al., 1987). Damage to the fetal membranes might occur in the same way as in fetal anuria (Los et al., 1992).

A qualitative model for feto-maternal AFP transfer in the normal situation and in early second-trimester oligohydramnios is presented in Figure 3. In this compartment-barrier model, AFP transfer is assumed to be a passive process according to AFP concentration gradients from the fetus to the mother, from the fetus to the amniotic fluid compartment, and from the amniotic fluid compartment to the mother across various membranes or barriers. A breakdown of a barrier results in higher AFP concentrations, and the absence of a barrier (infinite resistance for AFP transfer) in lower AFP concentrations in the distal compartment(s). The absence of the fetal urinary tract barrier between the fetus and the amniotic fluid compartment, or decreased fluid supply to the amniotic fluid in the case of intrauterine growth retardation, diminishes the amniotic fluid compartment with subsequent breakdown of the barrier between the amniotic fluid compartment and the mother (fetal membranes). Mechanical damage of this barrier has been suggested in early second-trimester oligohydramnios following threatened abortion or intrauterine instrumentation (Los et al., 1992). 


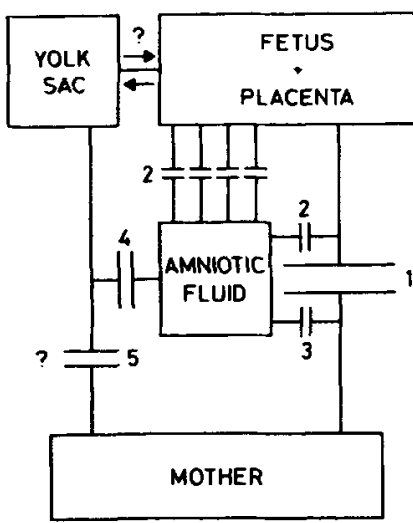

$\leq 12$ WEEKS

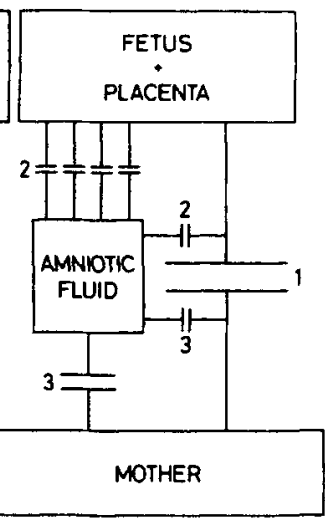

$\geq 16$ WEEKS

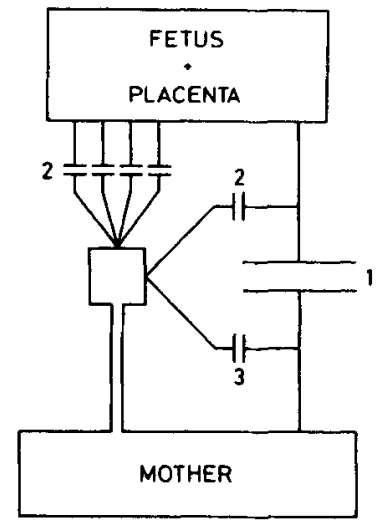

OLIGOHYDRAMNIOS

Figure 3. Compartment-barrier model for feto-maternal AFP transfer. On the left: situation before 12 weeks of gestation; in the middle: situation from 16 weeks of gestation onwards, after fusion of decidua parietalis and capsularis; on the right: situation in early second-trimester oligohydramnios. $1=$ Placental barrier between the fetus and mother; 2 =barriers between the fetus and amniotic fluid (fetal skin; urinary, gastrointestinal, and respiratory tracts; umbilical cord; and part of chorionic plate occupied by fetal vessels); 3 = barrier between amniotic fluid and mother (fetal membranes and part of chorionic plate not occupied by fetal vessels); 4 = barrier between yolk sac (extraembryonic coelomic space) and amniotic fluid; 5 =barrier between yolk sac (extraembryonic coelomic space) and mother (chorionic plate before fusion of amnion and chorion)

In the present study, fetal outcome was predominantly male both in the presence and in the absence of fetal malformations. This suggests that fetal membranes of male origin may be less resistant to damage than those of female origin. This has to be further substantiated.

Early second-trimester oligohydramnios seems to be a particular problem in multigravidae. Our data indicate a recurrence risk of early second-trimester oligohydramnios in both fetuses with and without urinary tract abnormalities. The finding of a normal MSAFP level in early second-trimester oligohydramnios strongly suggests fetal urinary tract pathology.

\section{ACKNOWLEDGEMENTS}

We are grateful to the Rotterdam Clinical Genetics Foundation for financial support, to P. Visser for drawing the figures, to Mrs J. du Parant for preparing the manuscript, and to Professor J. W. Wladimiroff for his encouraging support and critical review of the manuscript.

\section{REFERENCES}

Brock, D.J.H. (1976). Mechanisms by which amniotic fluid alpha-fetoprotein may be increased in fetal abnormalities, Lancet, ii, 345-346.

Dericks-Tan, J.S.E., Zehfuss, I., Taubert, H.D. (1982). Die Bedeutung von AFP und HCG in der ersten Schwangerschaftshälfte, Geburtshilfe Frauenheilkd., 42, 29-34.

Dyer, S.N., Burton, B.K., Nelson, L.H. (1987). Elevated maternal serum $a$-fetoprotein levels and oligohydramnios: poor prognosis for pregnancy outcome. Am. J. Obstet. Gynecol., $157,336-339$. 
Exalto, N. (1979). The early pregnancy. Morphologic and endocrine aspects, Ph.D. Thesis, Nijmegen.

Hackett, G.A., Nicolaides, K.H., Campbell, S. (1987). Doppler ultrasound assessment of fetal and utero-placental circulations in severe second trimester oligohydramnios. $B r . J$. Obstet. Gynaecol., 94, 1074-1077.

Kelly, R.B., Nyberg, D.A., Mack, L.A., Fitzsimmons, J., Uhrich, S. (1989). Sonography of placental abnormalities and oligohydramnios in women with elevated alpha-fetoprotein levels: comparison with control subjects, Am. J. Roentgenol., 153, 815-819.

Kloosterman, G.J. (1970). On intrauterine growth, the significance of prenatal care, Int. J. Gynaecol. Obstet., 8, 895-912.

Los, F.J., Pijpers, L., Jahoda, M.G.J., et al. (1989). Transabdominal chorionic villus sampling in the second trimester of pregnancy: feto-maternal transfusions in relation to pregnancy outcome, Prenat. Diagn., 9, 521-526.

Los, F.J., Beekhuis, J.R., Marrink, J., et al. (1992). Origin of raised maternal serum alphafetoprotein levels in second trimester oligohydramnios, Prenat. Diagn., in press.

McKusick, V. (1990). Mendelian inheritance in man. Catalogs of Autosomal Dominant, Autosomal Recessive, and X-Linked Phenotypes, 9th ed., Baltimore: John Hopkins University Press, 1115-1116.

Marrink, J., Sleijffer, D.Th., de Vries, E.G.E., Schraffordt Koops, H. (1990). Alphafetoprotein-lectin binding as a marker of tumour activity or liver damage, Eur. J. Cancer, 26, 969-972.

Richards, D.S., Seeds, J.W., Katz, V.L., Lingley, L.H., Albright, S.G., Cefalo, R.C. (1988). Elevated maternal serum alpha-fetoprotein with oligohydramnios: ultrasound evaluation and outcome, Obstet. Gynecol., 72, 337-341.

Ruoslahti, E., Seppälä, M. (1979). a-Fetoprotein in cancer and fetal development, $A d v$. Cancer Res., 29, 275-346.

Ruoslahti, E., Engvall, E., Pekkala, A., Seppälä, M. (1978). Developmental changes in carbohydrate moiety of human alpha-fetoprotein, Int. J. Cancer, 22, 515-520.

Sutcliffe, R.G. (1975). The nature and origin of the soluble protein in human amniotic fluid. Biol. Rev., 50, 1-33.

Toftager-Larsen, K. (1990). Carbohydrate heterogeneity of human alpha-fetoprotein in pregnancy. Methodological and clinical studies, Dan. Med. Bull., 37, 41-57.

United Kingdom Collaborative Study on Alpha-fetoprotein in Relation to Neural Tube Defects (1977). Maternal serum-alpha-fetoprotein measurement in antenatal screening for anencephaly and spina bifida in early pregnancy, Lancet, $\mathbf{i}, 1323-1332$.

Zerres, K., Völpel, M.-C., Weiß, H. (1984). Cystic kidneys, genetics, pathologic anatomy, clinical picture and perinatal diagnosis, Hum. Genet., 68, 104-135. 